\title{
Investigation of some performance characteristics and handball talent levels of male and female students
}

\author{
Harun GENÇ, Gökmen KILINÇARSLAN, İdris KAYANTAŞ, Akan \\ BAYRAKTAR
}

Bingöl University, School of Physical Education and Sports, Bingöl, Türkiye.

*This paper was presented (oral presentation) at the International Congress of Sports for All and Wellness will be held in AlanyalAntalya on 5-8 April 2018.

Address correspondence to H. Genc, e-mail:hgenc@bingol.edu.tr

\begin{abstract}
In this study, it was aimed to determine the performance characteristics and skill levels specific to the sport branch and to determine the talent and to direct the correct branch while the children with very high potential in our country are directed to the spore. The sample group of this study consisted of 124 volunteer middle school students, 62 girls 11,13 years and 62 boys 11,06 years, aged, who had never been trained in any sport branch in Ankara. The performance features include a vertical jump test, a long jump test, a $20 \mathrm{~m}$ speed run test, a health ball throw test, and a hand throw test for handball talent detection, triple jump shooting, throwing ball, throwing ball to the target on the wall, test was applied. Statistical analyzes of the measurements were made in the SPSS 22 program. When the total scores of the male and female students who applied the handball ability test battery were examined, it is determined that there are 17 female and 22 male students with good and very good level. As a result; It is thought that 15 male and 11 female learners may be more successful in the handball field than other students and therefore it is appropriate to direct these students to the handball branch.
\end{abstract}

Key words: Handball, Performance Features, Talent Selection.

\section{INTRODUCTION}

The skilled person is defined as a person who is above normal in a certain area but has not yet fully developed characteristics (1). Talent selection is to find people who are more likely to move forward in high-performance and performanceoriented training. This process lasts a long time. It should be decided by repeating the tests at various times by taking into account the training objectives and contents (2). Talent selection is the grouping of children to be directed to the sports branch that they can be successful at the possible earliest age (3). Purpose of talent selection is to identify and select sportsmen who have the best skills in a sport branch by extracting the unsuitable ones (4).

Sportive success is made possible by choosing a branch that is appropriate for young children and by directing and educating the determined children as a result of the selection of skills with test criteria depending on the specific body ability of this branch (5). In sports branches, the expectation of sportsmen from training is to maximize their performance. Physical fitness values including physical, physiological and anthropometric characteristics of athletes are important in talent selection. Sportive success is made possible by choosing a branch that is appropriate for young children and by directing and educating the determined children as a result of the selection of skills by test criteria depending on the specific ability of the branches (5). In sports branches, the expectation of sportsmen from training is to maximize their performance. Physical fitness values including physical, physiological and anthropometric characteristics of athletes are important in talent selection (6).

As in any sport branch, there must be a system integrity to select the most talented sportsmen in handball (7). In order to achieve high-level handball players, it is necessary to emphasize the importance of skill in addition to ability, because it is not always possible for individuals to be born capable of sports. Only overall skill is not enough for handball sports. For these reasons, the selection of sportsmen in handball should be made by taking into account both the skill level and talent level (8). 
The aim of this study was to determine some performance characteristics of middle school girls and boys and their abilities specific to the handball branch.

\section{MATERIALS \& METHOD}

The sample group of this study consists of 124 volunteer secondary school students living in Ankara province, 62 girls and 62 boys aged $10 \pm 1$ who have not been educated in any sport branch before.

\section{Data Collection Tools}

In the study, to determine some performance characteristics of the students; the vertical jump test, standing long jump test, $20 \mathrm{~m}$ sprint test, and seated medicine ball throw test was applied.

The students' handball talent were determined by Handball Talent Test Battery whose the validity and reliability study was conducted by Mülazımoğlu et al. (2009). Cronbach $\alpha$ values of the handball talent test battery were 0.71 in girls and 0.73 in boys. The reliability coefficient for each section in the test battery were as follows: r(girls)
$=0,68 ; 0,72 ; 0,97 ; 0,68 ; 0,77$ and 0,98, respectively, and $\mathrm{r}$ (boys) $=0,68 ; 0,73 ; 0,96 ; 0,64 ; 0,79$ and 0,98 , respectively. The handball test battery used in the study is composed of six sub-sections: the test of throwing a ball into a hoop from the air (shooting), the test of throwing a bouncing ball into a hoop (bounce shooting), the test of dribbling, the test of bringing down pins (bowling), the test of throwing a ball to a target on a wall (passing to the target), and the test of fast passing on a wall (speed pass) (9).

Statistical analysis of the data of the study was made using SPSS 22 software. The mean and standard deviation of the measured and tested values were calculated. Statistical significance level was accepted as $\mathrm{p}<0.05$.

\section{FINDINGS}

The sample group of this study consists of 124 volunteer secondary school students living in Ankara province, 62 girls and 62 boys aged $10 \pm 1$ who have not been educated in any sport branch before, and some performance characteristics and skill levels specific to handball branch were measured, and the data obtained were compared.

Table 1. Physical measurements of boys and girls

\begin{tabular}{lccccc}
\hline Variables & \multicolumn{2}{c}{ Boys } & Girls & \multirow{2}{*}{ Statistical sign. (p) } \\
\cline { 2 - 5 } & $\mathrm{n}$ & Mean \pm S.D. & $\mathrm{n}$ & Mean \pm S.D. & \\
\hline Age $($ year $)$ & 62 & $11.06 \pm 67$ & 62 & $11.13 \pm 0.58$ & .571 \\
\hline Height $(\mathrm{m})$ & 62 & $1.48 \pm 0.09$ & 62 & $1.46 \pm 0.09$ & .211 \\
\hline Weight $(\mathrm{kg})$ & 62 & $40.30 \pm 8.03$ & 62 & $39.01 \pm 8.75$ & .394 \\
\hline BMI $\left(\mathrm{kg} / \mathrm{m}^{2}\right)$ & 62 & $18.17 \pm 2.44$ & 62 & $18.11 \pm 2.92$ & .896 \\
\hline $\mathrm{P}<0.05$ & & & & &
\end{tabular}

In our study, the mean age was $11,13 \pm 0,58$ years in girls and $11,06 \pm 67$ years in boys; the mean height was $1,46 \pm 0,09 \mathrm{~m}$ in girls and $1,48 \pm 0,09 \mathrm{~m}$ in boys; the mean body weight was $39,01 \pm 8,75 \mathrm{~kg}$ in girls and $40.30 \pm 8.003 \mathrm{~kg}$ in boys. The mean BMI was $18,11 \pm 2,92 \mathrm{~kg} / \mathrm{m}^{2}$ for girls and $18,17 \pm 2,44 \mathrm{~kg} / \mathrm{m}^{2}$ for boys. There was no significant difference between the demographic characteristics of the male and female participants $(p>0.05)$. According to the table
2 , the average score of the test of throwing a ball into a hoop from the air (shooting) was $4,05 \pm 1,20$ for the boys and 3,98 $\pm 1,20$ for the girls. The average score of the test of throwing a bouncing ball into a hoop (bounce shooting) was $2,37 \pm 1,28$ for the girls and $3,10 \pm 1,28$ for the boys. The average score of the test of dribbling was $1,74 \pm 1,13$ for the girls and $2,06 \pm 1,25$ for the boys. 
Table 2. Comparison of Handball Talent Test Battery Scores of the Students by Gender

\begin{tabular}{|c|c|c|c|c|}
\hline Tests & Gender & $\mathrm{n}$ & Mean & Statistical sign. $(p)$ \\
\hline \multirow{2}{*}{$\begin{array}{l}\text { The test of throwing a ball into a hoop from } \\
\text { the air (shooting) }\end{array}$} & Girls & 62 & $3.98 \pm 1.20$ & \multirow{2}{*}{.767} \\
\hline & Boys & 62 & $4.05 \pm 1.20$ & \\
\hline \multirow{2}{*}{$\begin{array}{l}\text { The test of throwing a bouncing ball into a } \\
\text { hoop (bounce shooting) }\end{array}$} & Girls & 62 & $3.10 \pm 1.28$ & \multirow{2}{*}{$.002^{*}$} \\
\hline & Boys & 62 & $2.37 \pm 1.28$ & \\
\hline \multirow[t]{2}{*}{ The test of dribbling } & Girls & 62 & $2.06 \pm 1.25$ & \multirow{2}{*}{.135} \\
\hline & Boys & 62 & $1.74 \pm 1.13$ & \\
\hline \multirow[t]{2}{*}{ The test of bringing down pins (bowling) } & Girls & 62 & $2.77 \pm 1.01$ & \multirow{2}{*}{$.002^{*}$} \\
\hline & Boys & 62 & $2.21 \pm 0.94$ & \\
\hline \multirow{2}{*}{$\begin{array}{l}\text { The test of throwing a ball to a target on a wall } \\
\text { (passing to the target) }\end{array}$} & Girls & 62 & $4.00 \pm 1.00$ & \multirow{2}{*}{$.033^{*}$} \\
\hline & Boys & 62 & $3.60 \pm 1.07$ & \\
\hline \multirow[t]{2}{*}{ The test of fast passing on a wall (speed pass) } & Girls & 62 & $3.37 \pm 0.85$ & \multirow{2}{*}{$.000^{*}$} \\
\hline & Boys & 62 & $2.77 \pm 0.96$ & \\
\hline \multirow[t]{2}{*}{ Handball ability test total score } & Girls & 62 & $2.97 \pm 1.40$ & \multirow{2}{*}{.165} \\
\hline & Boys & 62 & $2.63 \pm 1.29$ & \\
\hline
\end{tabular}

$\mathrm{P}<0.05$

Table 3. The frequency and percentage distributions of students' Handball Test Battery measurements by gender

\begin{tabular}{|c|c|c|c|c|c|c|c|c|c|c|c|c|c|}
\hline \multirow{2}{*}{ 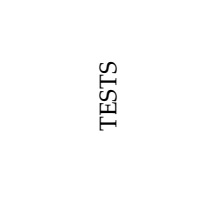 } & \multirow{2}{*}{ 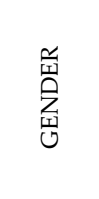 } & \multicolumn{2}{|c|}{ ○ } & \multicolumn{2}{|c|}{ 导 } & \multicolumn{2}{|c|}{ 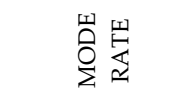 } & \multicolumn{2}{|c|}{ ठి } & \multicolumn{2}{|c|}{ 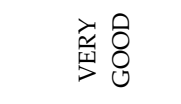 } & \multicolumn{2}{|c|}{ 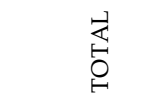 } \\
\hline & & 摇岂导 & $\therefore$ & 䁘岂导 & $\therefore$ & 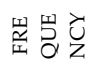 & $\therefore$ & 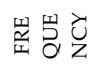 & $\therefore$ & 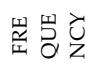 & $\therefore$ & 㱏岂总 & $\therefore$ \\
\hline \multirow{2}{*}{$\begin{array}{l}\text { the test of } \\
\text { throwing a ball } \\
\text { into a hoop } \\
\text { from the air } \\
\text { (shooting) }\end{array}$} & BOYS & 0 & 0 & 13 & 21 & 5 & 8.1 & 15 & 24.2 & 29 & 46.7 & 62 & 100 \\
\hline & GIRLS & 3 & 4.8 & 6 & 9.7 & 7 & 11.3 & 15 & 24.2 & 31 & 50 & 62 & 100 \\
\hline \multirow{2}{*}{$\begin{array}{l}\text { the test of } \\
\text { throwing a } \\
\text { bouncing ball } \\
\text { into a hoop } \\
\text { (bounce } \\
\text { shooting) }\end{array}$} & BOYS & 8 & 12.9 & 15 & 24.2 & 11 & 17.7 & 19 & 30.6 & 9 & 14.5 & 62 & 100 \\
\hline & GIRLS & 20 & 32.3 & 19 & 30.6 & 6 & 9.7 & 14 & 22.6 & 3 & 4.8 & 62 & 100 \\
\hline \multirow{2}{*}{$\begin{array}{l}\text { the test of } \\
\text { dribbling }\end{array}$} & BOYS & 30 & 48.4 & 13 & 21.0 & 5 & 8.1 & 13 & 21.0 & 1 & 1.6 & 62 & 100 \\
\hline & GIRLS & 38 & 61.3 & 10 & 16.1 & 8 & 12.9 & 5 & 8.1 & 1 & 1.6 & 62 & 100 \\
\hline \multirow{2}{*}{$\begin{array}{l}\text { the test of } \\
\text { bringing down } \\
\text { pins (bowling) }\end{array}$} & BOYS & 6 & 9.7 & 19 & 30.6 & 23 & 37.1 & 11 & 17.7 & 3 & 4.8 & 62 & 100 \\
\hline & GIRLS & 16 & 25.8 & 22 & 35.5 & 20 & 32.3 & 3 & 4.8 & 1 & 1.6 & 62 & 100 \\
\hline \multirow{2}{*}{$\begin{array}{l}\text { the test of } \\
\text { throwing a ball } \\
\text { to a target on a } \\
\text { wall (passing to } \\
\text { the target) }\end{array}$} & BOYS & 1 & 1.6 & 4 & 6.5 & 13 & 21.0 & 20 & 32.3 & 24 & 38.7 & 62 & 100 \\
\hline & GIRLS & 3 & 4.8 & 6 & 9.7 & 16 & 25.8 & 26 & 41.9 & 11 & 17.8 & 62 & 100 \\
\hline \multirow{2}{*}{$\begin{array}{l}\text { the test of fast } \\
\text { passing on a } \\
\text { wall (speed } \\
\text { pass) }\end{array}$} & BOYS & 2 & 3.2 & 7 & 11.3 & 21 & 33.9 & 30 & 48.4 & 2 & 3.2 & 62 & 100 \\
\hline & GIRLS & 6 & 9.7 & 17 & 27.4 & 26 & 41.9 & 11 & 17.8 & 2 & 3.2 & 62 & 100 \\
\hline \multirow{2}{*}{$\begin{array}{l}\text { Handball ability } \\
\text { test total score }\end{array}$} & BOYS & 13 & 21.0 & 10 & 16.1 & 17 & 27.4 & 10 & 16.1 & 12 & 19.4 & 62 & 100 \\
\hline & GIRLS & 15 & 24.2 & 16 & 25.8 & 14 & 22.5 & 11 & 17.8 & 6 & 9.7 & 62 & 100 \\
\hline
\end{tabular}


The average score of the test of bringing down pins (bowling) was 2,21 $\pm 0,94$ for the girls and $2,77 \pm 1,01$ for the boys. The average score of the test of throwing a ball to a target on a wall (passing to the target) was $3,60 \pm 1,07$ for the girls and $4,00 \pm 1,00$ for the boys. The average score of the test of fast passing on a wall (speed pass) was $2,77 \pm 0,96$ for the girls and $3,37 \pm 0,85$ for the boys. Finally, the total score of the handball test battery was $2,63 \pm 1,29$ for the girls and $2,97 \pm 1,40$ the boys. There was a statistically significant difference between the scores of boys and girls for the test of throwing a bouncing ball into a hoop (bounce shooting), the test of bringing down pins (bowling), the test of throwing a ball to a target on a wall (passing to the target) and the test of fast passing on a wall (speed pass) $(p<0.05)$. There was no statistically significant difference between the scores of boys and girls for the test of throwing a ball into a hoop from the air (shooting), the test of dribbling, and handball ability test total score $(p>0.05)$.

According to the table 4, there was a statistically significant difference between vertical jump test, standing long jump test, $20 \mathrm{~m}$ sprint test, seated medicine ball throw test results of the girls and boys participating in the study $(\mathrm{p}<0.05)$.

Table 5. The comparison of performance test scores of boys with good and very good results and the scores of boys with bad results for handball test battery

\begin{tabular}{|c|c|c|c|c|c|}
\hline \multirow[t]{2}{*}{ Variables } & \multicolumn{2}{|c|}{$\begin{array}{l}\text { The boys with good and very } \\
\text { good results in handball test } \\
\text { battery }\end{array}$} & \multicolumn{2}{|c|}{$\begin{array}{l}\text { The boys with bad results in } \\
\text { handball test battery }\end{array}$} & \multirow[t]{2}{*}{ Statistical sign. (p) } \\
\hline & $\mathrm{n}$ & Mean \pm S.D. & $\mathrm{n}$ & Mean \pm S.D. & \\
\hline Vertical jump test $(\mathrm{cm})$ & 15 & $28.60 \pm 3.81$ & 40 & $23.52 \pm 5.08$ & $0.001^{*}$ \\
\hline Standing long jump test $(\mathrm{cm})$ & 15 & $1413.63 \pm 11.45$ & 40 & $122.58 \pm 19.23$ & $0.000^{*}$ \\
\hline $20 \mathrm{~m}$ sprint test $(\mathrm{s})$ & 15 & $3.78 \pm 0.35$ & 40 & $4.55 \pm 0.50$ & $0.000^{*}$ \\
\hline Seated Medicine Ball Throw (cm) & 15 & $476.60 \pm 90.78$ & 40 & $411.50 \pm 73.89$ & $0.009^{*}$ \\
\hline
\end{tabular}

According to the total handball test scores, the number of boys with a mean age of $11,06 \pm 67$ years $(\mathrm{n}=62)$ were found to be $10(21.0 \%)$ at a very bad level; $10(16.1 \%)$ at bad level; $17(27.4 \%)$ at medium level; $10(16.1 \%)$ at good level; and 12
(19.4\%) at very good level. According to this data, the performance test results of the 15 of 22 boys who had good and very good score were found to be significantly better than those of other students.

Table 6. The comparison of performance test scores of girls with good and very good results and girls with bad results for handball test battery

\begin{tabular}{lccccc}
\hline \multicolumn{1}{c}{ Variables } & \multicolumn{2}{c}{$\begin{array}{c}\text { The girls with good and } \\
\text { very good results in } \\
\text { handball test battery }\end{array}$} & $\begin{array}{c}\text { The girls with bad results in } \\
\text { handball test battery }\end{array}$ & $\begin{array}{c}\text { Statistical sign. } \\
(\mathrm{p})\end{array}$ \\
\cline { 2 - 5 } & $\mathrm{n}$ & Mean \pm S.D. & $\mathrm{n}$ & Mean \pm S.D. \\
\hline Vertical jump test $(\mathrm{cm})$ & 11 & $24.12 \pm 2.77$ & 45 & $20.24 \pm 5.05$ & $0.018^{*}$ \\
\hline Standing long jump test $(\mathrm{cm})$ & 11 & $127.61 \pm 20.40$ & 45 & $107.01 \pm 19.25$ & $0.003^{*}$ \\
\hline $20 \mathrm{~m}$ sprint test $(\mathrm{s})$ & 11 & $3.71 \pm 0.26$ & 45 & $3.99 \pm 0.54$ & $0.016^{*}$ \\
\hline Seated Medicine Ball Throw $(\mathrm{cm})$ & 11 & $432.55 \pm 48.25$ & 45 & $381.91 \pm 46.90$ & $0.002^{*}$ \\
\hline $\mathrm{P}<0.05$ & & & &
\end{tabular}

In the study, there were 15 girls $(24,2 \%)$ at the very bad level, $16(25,8 \%)$ at the bad level, 14 $(22,5 \%)$ at the moderate level, $11(17,8 \%)$ at the good level and $6(9,7 \%)$ at very good level (a total of 62 ). According to these data, there are 17 girls who get DISCUSSION \& CONCLUSION

In the present study, the mean age was $11,13 \pm 0,58$ years for girls and $11,06 \pm 67$ years for boys; height average was $1,46 \pm 0,09 \mathrm{~m}$ for girls and $1,48 \pm 0,09 \mathrm{~m}$ for boys; body weight average was $39,01 \pm 8,75 \mathrm{~kg}$ for girls and $40,30 \pm 8,03 \mathrm{~kg}$ for boys. The mean BMI was $18,11 \pm 2,92 \mathrm{~kg} / \mathrm{m}^{2}$ for girls and $18,17 \pm 2,44 \mathrm{~kg} / \mathrm{m}^{2}$ for boys. There was no significant difference between the demographic characteristics very good and good scores. In addition, the performance test results of 11 girls were also found to be better than other students at 0.05 significance level.

of the boys and girls ( $p>0.05)$. Bozdoğan et al. (10) conducted a study on the badminton players. For both boys and girls, the mean age was 12,05 \pm 0.05 and $12,05 \pm 0,05$ years, the mean height was $1.43 \pm 0.45 \mathrm{~m}$ and the mean body weight was $43.5 \pm$ $1.2 \mathrm{~kg}$. In a study performed on tennis players, the mean age was $11,21 \pm 1,08$, the mean height was $1.52 \pm 0.11 \mathrm{~m}$, the mean body weight was $44.76 \pm 7.87$ $\mathrm{kg}$ for male students. These numbers were 
$11,05 \pm 1,51$ years, $1,48 \pm 0,08 \mathrm{~m}$, and $35,84 \pm 5,75 \mathrm{~kg}$, respectively (11). In a study conducted in Slovenia, the height average was $145.4 \pm 6.8 \mathrm{~cm}$, and body weight averages were $38.0 \pm 8.1 \mathrm{~kg}$ in girls; and the body height averages was $145.5 \pm 6.2 \mathrm{~cm}$ and body weight averages were $38.9 \pm 8.2 \mathrm{~kg}$ in boys (12). In a similar study conducted by Örjan et al., (13) the average body mass index was $18,3 \pm 3,0 \mathrm{~kg} / \mathrm{m}^{2}$ and $18,1 \pm 2,9 \mathrm{~kg} / \mathrm{m}^{2}$ for girls and boys who do not play sports, respectively.

In our study, vertical jump test mean was 22,92 $\mathrm{cm}$ for boys and $20,58 \mathrm{~cm}$ for girls; the mean standing long jump test was $126,27 \mathrm{~cm}$ for boys and $105,61 \mathrm{~cm}$ for girls; 20-meter sprint test mean was $4,05 \mathrm{~s}$ for boys and $4,66 \mathrm{~s}$ for girls. The seated medicine ball throw averages were $418,76 \mathrm{~cm}$ in boys and 384,76 cm in girls. Yikılmaz (14) reported that the vertical jump averages of boys with a mean age of 10,84 years were $25,70 \mathrm{~cm}$ and vertical jump averages of girls with a mean age of 10,67 years were $23,48 \mathrm{~cm}$. In another study, vertical jump averages of 11-year-old girls were $31.40 \pm 5.75 \mathrm{~cm}$ (15). Kurban (16) investigated the effect of football training on technical development of children, the mean pre-test values of vertical jump test for boys whose ages were $11,67 \pm 14,30$ years were $23,00 \pm 6,99$ $\mathrm{cm}$ and the final test values were $25,80 \pm 6,23 \mathrm{~cm}$. In the study on the relationship between match performance and field tests in tennis players aged 810 , it was found that the mean standing long jump test of male tennis players aged 10 years was $1.54 \pm 0,13 \mathrm{~m}$ (17). Pilianidis et al. (18) reported that the mean standing long jump in 8-11 age group was $140 \pm 0,23 \mathrm{~cm}$. In a study that some anthropometric and motoric characteristics of 10-12 years-old boys who did and did not perform athletic sport education were compared, the mean standing long jump average was $140.96 \pm 17.97$ (19). In another study, the average of $20 \mathrm{~m}$ sprint test scores of girls aged 11 years in primary education in Antalya was $4.22 \pm 0.38 \mathrm{~s}$ (15). Yazarer et al. (20) found the average of $20 \mathrm{~m}$ sprint test values of males aged 11 years as $4,18 \pm 0,30$ s. Finally, Pekel (21) reported that the average of seated medicine ball throwing test was $481,9 \mathrm{~cm}$ in 11-year-old girls and $531,6 \mathrm{~cm}$ in 11 year-old boys. The values in our study and the values in other studies are generally parallel. In addition, there are some differences; The reasons for these differences are thought to be caused by genetic, environmental factors, cultural and socioeconomic differences. In addition, in the present study, there was no statistically significant difference in height, weight, BMI values of boys and girls. This may be due to the fact that children of this age are not yet in adolescence.

In our study, the percentage of handball ability test battery score was found for girls to be $24,2 \%$ for very bad level, $25,8 \%$ for bad level, $22,5 \%$ for medium level, $17,8 \%$ for good level and $9,7 \%$ for the very good level. For the boys, it was found to be $21,0 \%$ for very bad level, $16,1 \%$ for bad level, $27,4 \%$ for moderate level, $16,1 \%$ for good level and 19,4\% for the very good level. Mülazımoğlu (22) conducted a study on female and boys with an average age of $9 \pm 1$, handball test battery percentage of girls $(n=$ 472 ) was $6,99 \%$ for very bad level, $20,34 \%$ for bad level, $32,84 \%$ for medium level, $28,81 \%$ for good level and $11,02 \%$ for very good level. For boys $(n=418)$, the percentages were found to be $5,02 \%$ for very bad level, $17.7 \%$ for a bad level, $37,06 \%$ for medium level, 30,62\% for good level and $9.57 \%$ for the very good level. Yavaş (23) reported that handball test battery score was found for girls ( $n=182$ ) to be $20,3 \%$ for very bad level, $28,6 \%$ for bad level, $22,0 \%$ for medium level, 20,3\% for good level and $8,8 \%$ for very good level. For the boys $(\mathrm{n}=184)$, it was found to be $10,9 \%$ for very bad level, $23,9 \%$ for bad level, $29,9 \%$ for medium level, $25,5 \%$ for good level and $9,8 \%$ for very good level. Due to the differences between the total number of subjects in our study and the studies conducted by Mülazımoğlu (22) and Yavaş (23), there were differences between the distribution of percentages, but, in general, it is observed that the students are gathered in the moderate level and male students are more successful than female students, so there is parallelism between the studies. Since the physical and physiological differences of puberty between boys and girls in this age do not start yet and since boys in school-age participate more in sporting activities than girls in our country, the male students achieved better performance results than female students in the present study.

As a result, it is seen that determining the children with suitable body structure for sports branches and selecting the appropriate branch and directing them by taking into consideration the age of starting the sport are important in the talent selection. In addition, it is important to apply special test batteries to children to be selected and to determine sports skills peculiar to the branches.

A total of 124 girls and boys participated in our study. The results of the handball talent test of 17 (\% $27.5)$ girls and 22 (35.5\%) boys were identified as good and very good. At the same time, the 
performance test results of $11(17.8 \%)$ girls and 15 $(24.2 \%)$ boys were determined to be better from other students at the level of 0.05 significance level

\section{REFERENCES}

1. Acar MF. Training for Children and Young People in Football with Corporate Basis, Meta Basım, İzmir, 2000.

2. Peltola E. Talent Identification, New Studies in Athletics, 1992; 7 (3): 7-12.

3. Kasap H. Choice of talent in sport and its status in our country, Turkey Physical Education Teacher of Youth and Sports Club Association, Sport Science Magazine, 1991; 5:12.

4. Alabin V, Nischt G, Jefinov W. Talent Selection. Modern Athlete and Coach, 1980; 18: 36-37.

5. Tutkun E. Establishment of Talent Selection Model of Primary School Children in Samsun, PhD Thesis, Ondokuz Mayis University, Health Sciences Institute, Department of Physical Education and Sports, Samsun, 2002.

6. Zorba E, Sevim Y, Ziyagil MA. Comparison of some anthropometric and motoric structure of Turkey and Azerbaijan's national handball team Young lady, Selcuk University and School of Sports Physical Education and Sport Science Journal, 2000; 2 (1): 24.

7. Çeliksoy MA. Theory and Practice in Handball, Anadolu Üniversitesi Yayınları, 1996; 195-202.

8. Çeliksoy MA. Handball Teaching Methods and Applications in Small Age Groups, Anadolu University Publications, Eskişehir, 2000; 181-5.

9. Mülazımoğlu O, Koç H, Erol AE, Kaya M, Ayan V. Validity and Reliability Study of Handball Talent Test Battery. EJournal Of New World Sciences Academy Sports Sciences, 2009; 4 (4); 300-12.

10. Bozdoğan Kızılet T, Kızılet A. The Relationship Between Back and Leg Strength with Agility Ability in Badminton Players in Developmental Age (11-13 Years), Gaziantep University Journal of Sport Sciences, 2017; 2 (3): 69-82.

11. Diker G, Zileli R, Özkamçı H, Ön S. Evaluation of Some Physiological and Biomotor Characteristics of Young Tennis Players, International Journal of Sport, Exercise and Training Science, 2017; 3 (1): 25-32.

12. Jurak G, Kovac M, Strel J. Impact of theAdditional Physical Educational Programme on the Physicaland Motor Development of 7-to 10 Year Old Children. Kinesiology, 2006; 38 (2): 105-115.

13. Örjan E, Kristjan O, Björn E. Physical Performance and Body Mass index in Swedish Children and Adolescents, Scan Jour of Nut, 2005; 49 (4): 172-179. and these students should be directed to the handball as an appropriate sports branch.

14. Yıkılmaz A. Evaluation of Performance-Related Physical Fitness of Primary School and Secondary School Students, Master Thesis, University of Gaziantep, Health Sciences Institute, Gaziantep, 2014

15. Turgut A, Çetinkaya V. Determination of Some Motor Characteristics in 6-11 Age Group Girls. 9th International Sports Science Congress. 3-5 November, Muğla, 2006.

16. Kurban M. Investigation of the Effect of Football Training on the Technical Development of 10-13 Age Group Children, Master Thesis, Selcuk University, Health Sciences Institute, Department of Physical Education and Sports, Konya, 2008.

17. Akşit T, Özkol ZM. Evaluation of the Relationship Between Match Performance and Field Tests in 8-10 Age Tennis Players, 9th International Sports Science Congress Proceedings Book, 3-5 November, Muğla, 2006.

18. Pilianidis T. Eurofit Applications of 8-11 Year-Old Children in Primary Schools, İrakliyo Physical Education Alumn Association Periodical Publication. 2004; 16-17: 21-32.

19. Gül GK, Seyrek E, Sugurtin M. The Comparison of Some Anthropometric Properties Between 10-12 Age Basic Athletics Sports Training and Non - Male Boys9th International Sports Science Congress Proceedings Book, 3-5 November, Muğla, 2006

20. Yazarer İ, Taşmektepligil MY, Ağaoğlu YS, Ağaoğlu SA, Albay F, Eker H. Physical Evaluation of Two Monthly Developments of the Groups Attending Basketball Activities in Summer Sports Schools, SPORMETRE Journal of Physical Education and Sport Sciences, 2004; II(4): 163-70.

21. Pekel HA. Normative Study on Some Variables in 10-12 Year Old Children Depending on Talent Search in Athletics (Ankara Case) PhD Thesis, Gazi University, Health Sciences Institute, Department of Physical Education and Sports, 2007.

22. Mülazımoğlu O. Investigation of Specific Skill Levels of Sports Branches of Somatotype Structures Suitable for Sports (Ankara Province Case), PhD Thesis, Gazi University, Health Sciences Institute, Department of Physical Education and Sports, 2007.

23. Yavaş A. Investigation of Hentbole Specific Ability Levels of 9-11 Year Old Children, Master Thesis, Selcuk University, Health Sciences Institute, Sports Management, 2008. 